\title{
Youth Idleness in Indonesia
}

\author{
Elfindri ${ }^{1}$, Bemby Soebiakto ${ }^{2}$, Harizal $^{3} \&$ Jahen F. Rezki ${ }^{4}$ \\ ${ }^{1}$ Faculty of Economics, Andalas University, Padang, West Sumatra, Indonesia \\ ${ }^{2}$ Faculty of Economics, Sriwijaya Universtiy, Palembang, South Sumatra, Indonesia \\ ${ }^{3}$ Ministry of Education and Culture, Indonesia \\ ${ }^{4}$ Institute for Economic and Social Research, LPEM-FEUI, Jakarta, DKI Jakarta, Indonesia \\ Correspondence: Elfindri, Faculty of Economics, Andalas University, Padang, West Sumatra, Indonesia. E-mail: \\ elfindribana@gmail.com
}

Received: December 31, 2014 Accepted: February 16, 2015 Online Published: May 16, 2015

doi:10.5539/ass.v11n13p251 URL: http://dx.doi.org/10.5539/ass.v11n13p251

\begin{abstract}
This study is concerned with the issue of youth idleness in Indonesia. Soaring idleness at a younger age has a serious impact on economic and social aspects, which have been discussed in various literatures recently. A limited research available on it is in the context of Indonesia. In this paper, we assess models on the probability of youth as potential job seekers denoted as unemployment as well as passive job seekers, called as 'idle' youth, and try to understand contributing factors to explain both youth idleness evidences. By analyzing data from 2012 Indonesia National Socioeconomic Survey Data (SUSENAS), this study observes important results of increasing idleness among middle and upper groups of households. Our data shows youth idleness is not always associated with poverty and lower economic status. We discuss the implication of this study.
\end{abstract}

Keywords: youth idleness, Indonesia, jobs, economics, and unemployment

\section{Introduction}

A new phenomenon behind demographic bonuses of Indonesia was increasing number of young population (Mason \& Kinugasa, 2008) (Note 1). Until recently, 25.6 percent of population is younger age cohort (15-24 years) and this proportion still increases until 2030 significantly (Note 2). This figure is also similar to the past experiences in countries of the growing economy in South and Southeast Asian (Economist, 2013; Banerji et al., 2013). More interestingly, a remarkable achievement of economic growth (an average 5-6\%) during past decades is followed by declining open unemployment from $9.62 \%$ in 2004 (March) to 5.92\% in 2013 (March) (Manning \& Sumarto, 2011).

The benefits of economic growth in Indonesia have not been always followed by the equal employment opportunity. At the same period, the growth of population classified as 'idle' fluctuated and there was no a declining indication as much as open unemployment (Note 3). The number of open 'idle' population was 7.5 million in 2004 and it fluctuated since 2013 ranging from 6.7 to 8.2 million (BPS, 2013) (Note 4).

The youth population (15-24 years) also consumes health services, technology as well as costly education; however, their pattern of time behavior is different from more adult (25-65 years) due to differences in their needs and services. Some were perhaps already actively involved in the labour market, especially those who cannot pursue higher education until sarjana level (bachelor degree). The youth population is a critical group in terms of human capital development, through education and health, as the youth is just the last stage to enter the labour force. Failing to provide better, affordable and accessible education and health services, the youth may then transform into unproductive labour force for the economy (Note 5).

In the Indonesian social policy context, the significance of youth idleness analysis stems from various reasons. First, increase in expansion of education in Indonesia has been followed by the increase in number of children who were dropout during transition period of schooling (Aizer et al., 2014). Enrolment rate of schooling declined from primary to lower secondary and also from lower secondary to upper secondary schools (Fernandez, 2014). As a result, the transition from schooling into labour market activities has been subject to question as to what happened with young population activities.

Second, doubt soars that expansion of equity in education is not followed by the increase in the quality of school 
(Suryadarma, 2011; Elfindri \& Rezki, 2014). Among school graduates, they mainly are younger age who do not have adequate skills and have limited cognitive development (Almeida, Behrman, \& Robalino, 2012) as well as inadequate soft skills capability (Banerji et al., 2013). It becomes evident that Indonesia is a country with low cognitive achievements from various education measurements, which could impact youth activities (Note 6).

Among school graduates, the duration of unemployment is a particular interest of the previous study; either theoretically explained how labour supply and demand operated (Salant, 1977; Mazzocco et al., 2014) or its empirical trend such as a case of Indonesia (Manning \& Sumarto, 2011). Much of the previous studies dealt with the economically active young population, but was less concerned with the economically inactive young population (Note 7).



Figure 1. Number of unemployment* and "idle" population in Indonesia

*) Unemployment: Looking for work, establishing a new business/firm, hopeless of job and Have a job in future start;

**) Activities not in labour force, nor in school, not having activities related with household.

Source: National Labour Force Survey 2004, 2005, 2006, 2007, 2008, 2009, 2010, 2011, 2012, and 2013.

Youth idle is a serious population phenomenon along with increasing youth underutilization. They do not enter labour market nor at the time of survey conducted being as students. According to Economist (March, 2013), youth idleness is a potential for economy because they potentially contribute to increased national economy (Belfiels \& Hendry, 2012). Until recently, there have limited understanding of their characteristics and how the individual and the household characteristics contributed to explain variations of idleness of youth accordingly.

This paper comprises 5 sections. Section 2 addresses recent literatures discussing the issues of idleness and seeking which potential factors have contributed to increase or decline in youth 'idleness'. Section 3 analyses the data to be used for this study, starting with the measurement of idleness and explaining the definition of variables used for this study. Section 4 exposes findings of the study and discussions. Section 5 comes up with conclusion.

\section{Survey of Literatures}

Young population may be idle when they are in a period transition from school to active in labour market. According to a labour force concept, economically active populations are individual ages above 15 years who are actively in particular job or seeking for job. Unemployment is often seen as situation of a person who is not at school anymore. He or she is not in household activities but a person actively seeking a job or temporary seeking the job (BPS, 2013).

Considering their being economically passive, either in labour force or at school, they are often considered as 'else'. For those who are classified as 'else' they are not included as economically active population (Note 8). In the earlier 1990, the similar questions have been posed to observe labor force data. Their main activities were to leave their school due to a certain condition. They are not active yet in labour force or may prepare for entering the next school.

Some literatures provided an examination and tried to answer who they are. The origin of literatures concerning the relationship between capitalism and idleness in the mid 17s has been examined by Adelman (2011). The context of selected Asian Tribes has been discussed by Alatas (1977). In general, younger age people classified as 'idle' accounted for $10-15 \%$ of total youth population. The use of capital and the origin of lazy natives because of uneducated are of the main factors contributing to youth idleness (Note 9). 
According to a research (Ireys et al., 1996) conducted for people with disabilities, it was observed that 23\% of the samples were classified as idle. Mentally retarded youths were two to three times more likely to go to school compared to those with chronic physical illness alone. Since the disability index is beyond $1-2 \%$ of the total population (Elfindri \& Jalal, 2014), youth idle is not always directly caused by disability. Among 'idle' youth, only around $2-3 \%$ of them are due to disability. Most of them are characterized in various social problems and have lower education background and a few skills.

Together with physical reasons, attention must be paid to individual characteristics of youth. Understanding various characteristics of youth, like marital status, gender, and residence location, makes clearer picture of this issue. Married individuals tended to go into labour market because of their breadwinning responsibility and less likely to become idle. Since parental responsibility for breadwinning is generally male, idleness for women is predicted much higher compared to male counterparts. In this survey, the three characteristics of youth would be seen in the context of youth idleness status.

Understanding education background of youth in Indonesia's context may be useful to determine which level of education explained variation of idleness. The shadow market wage argument proposed by Almeida et al (2013) suggested that increase in education of individuals might attract them to enter wageworkers by becoming job seekers and less likely become idle. It is possible to look at difference in idleness according to types of education (vocational versus general), level of education (from lower education to higher education), and either formal or informal certificate holders. Certificate and vocational schools may reduce the probability of youth becoming idle, or vice versa.

For upper middle education, policy has been made by Ministry of Education, Republic of Indonesia to increase the number of students entering vocational schools and reduce the general schools for its target student's population (Jalal et al., 2012). The aim of policy is to improve students' preparation for readily entering job opportunity with basic skills. The composition of general schools has made over $60 \%$ of students enter general schools system, the rest go to the vocational ones. The government of Indonesia initiates to reduce number of students in general schools and manages to raise proportion of students in vocational schools system. We do not have a clear picture how the education background influences youth performances in labour markets.

To fulfill the need of education, the government of Indonesia also encourages the ministry of religious affairs to increases the number of religious schools. This serves around $6 \%$ of total students entering religious senior school such as Madrasah schools through either normal or boarding school systems (Ministry of Religious Affairs, 2007). The primary objective of religious schools is to provide students with reading, math and basic sciences in addition to basic religious knowledge. Doubts abound concerning the quality religious schools (Permani, 2011), which could impact their graduate performance. One of the ways to look at how youth performance after graduating from religious schools is by looking at youth idleness performances. This idle status can be compared with those who graduate from general and vocational schools.

Another critical issue is that government of Indonesia has introduced a formal certificate program for young population interested in continuing their further schools. Some may use it to get a job. Equalizing program (Program Penyetaraan) through "Kejar Paket A, B and C" has increased access of people to get formal certificate around $2-3 \%$ of total population. This policy has helped increase the fulfillment of equity in education achievements (Jalal et al., 2012) (Note 10). Using 2012 Susenas data, Elfindri and Rezki (2014) estimate that rates of economic return to non-formal education is almost zero. Comparison with other types of schools turns out to be an alternative way to see how idleness status of non-formal education.

Household characteristics are important factors contributing to the probability of youth either active or passive in their allocation of time. Since Becker (1965) introduced time as a resource for individual (and latter for household when they are married), the impact of household resources on individual decision to work can be seen. Later, Thomas (2000) extended his analysis by considering intra-household resources allocation. An increase in household income tended to reduce the probability of children to enter job market. Different from the household factors, according to Ljungqvist (2000), countries with a high ratio of unskilled labours have a very low wage compared to those of skilled workers.

The demand for leisure such as being 'idle' may increase since the children live with their parents who have greater income. In society with a strong family engagement, young children may still depend on their parents. When parental income is still sufficient, this may influence individual time decision. Lee and Newhouse (2013) reported a strong correlation between cognitive skills and labour market outcomes. A study reported by Mazzocco et al. (2013) indicated the importance of marriage status on supply of time for women. The behavior 
of women to supply labour is different from man. In the context of youth we do not know differences in idleness according to their gender status.

\section{Data and Methodology}

Our data come from the 2012 Indonesia Susenas (Survey Sosial Ekonomi Nasional) that contain surveyed employment record of population aged 10 years and above. The Susenas is nationally representative survey conducted by the Indonesian Bureau of Statistics (BPS) that began since earlier 1971. It interviewed individual adult people on employment related questions.

We select young age population of 15-24 years for those who were active in labor force, either working (n) or seeking the job (u). We also include the younger age who were either not in school or not active in household activities. We denote them as else $\mathrm{i}_{\mathrm{i}}$. Thus we define economically active population for those:

$$
\mathrm{P}_{\mathrm{i}}=\mathrm{n}_{\mathrm{i}}+\mathrm{u}_{\mathrm{i}}+\mathrm{else}_{\mathrm{i}}
$$

where $P_{i}$ is potential working age population ${ }_{i}$ we calculate only for those 15-24 years of age. "Idle' younger age population during transition from schooling to work. They can be defined as "passive" potential labour force $\left(\mathrm{Idle}_{\mathrm{i}}\right)$. For that economically active population, we denote here as active potential labour force $\left(\mathrm{Un}_{\mathrm{i}}\right)$.

Active potential labour force:

$$
\mathrm{Un}_{\mathrm{i}}=\mathrm{u}_{\mathrm{i} /} \mathrm{P}_{\mathrm{i}}
$$

And for passive potential labour force:

$$
\text { "Idle }{ }_{i} "=\text { else }_{i} / P_{i}
$$

Table 1. Mean and standard deviation of variable used

\begin{tabular}{lll}
\hline Variable & Mean & Std. Dev. \\
\hline "idle ${ }^{\text {' }}$ & 0.0951694 & 0.2934517 \\
$\mathbf{U}_{\mathbf{i}}$ & 0.1204204 & 0.3254559 \\
Sex & 0.8110845 & 0.3914455 \\
Residence & 0.4269711 & 0.4946431 \\
Unmarried & 0.8651039 & 0.3416160 \\
Education b/ & & \\
ED-1 & 0.3432074 & 0.4747849 \\
ED-2 & 0.2267515 & 0.4187348 \\
ED-3 & 0.2424267 & 0.4285554 \\
ED-4 & 0.0516000 & 0.2212204 \\
ED-5 & 0.1020819 & 0.3027591 \\
ED-6 & 0.0017688 & 0.0420203 \\
ED-7 & 0.0047981 & 0.0691027 \\
Expenditures c/ & & \\
HH1-poor & 0.2000163 & 0.4000163 \\
HH2-near poor & 0.1999959 & 0.4000010 \\
HH3-medium & 0.1999959 & 0.4000010 \\
HH4-uper med. & 0.1999959 & 0.4000010 \\
Health status d/ & & \\
Ailment & 0.1531737 & 0.3601585 \\
Disturb & 0.0796162 & 0.2707008 \\
\hline
\end{tabular}

None a) One of the goals of our study is to characterize youth probability of seeking the job as well as 'idle' across these age cohorts. Toward this end, we select only those who are already 15-24 years where these ages are transition from school to work. As a consequence, we classified respondents into three activities categories as follows: (a) having activity (n); (b) seeking the job (u); (c) 'else'. We exclude respondents who were active at school and respondents reported as having home-related activities. b/ higher education as a reference. c/ 
economic factor is measured through consumption, and it is classified into 5 groups, lowest groups where consumption expenditures at the $20 \%$ lowest, and the richest as a reference categories. $\mathrm{d} / \mathrm{dilment}$ is an alternative way to look at the health condition of the respondents. Ailment just reflects qualitative measurement of health status, when the respondents answer they ever have an illness problem during a week before the survey, we denote them as 1 . The next question is whether illness has an impact on working activity, if the respondents answer yes we denote them one.

Our main interest in this paper is to look at various factors that influence the probability of youth to become unemployed $\left(\mathrm{Un}_{\mathrm{i}}\right)$ or idleness ' $\mathrm{idle}_{\mathrm{i}}$ '. These factors have been discussed earlier as individual factors, household factors, levels and types of education of respondents as a proxy of individual characteristics of human capital. We study the influence of household income to see whether the decision of youth to seek the job (u) or to stay at else. We classified household income into five categories: the lowest $(\mathrm{HH}-1=<20 \%)$, near poor, upper medium, until highest income groups. We expect that idle youth is also stimulated by households support.

Susenas 2012 also contains questions on health related aspects through qualitative ailment question. Respondents were asked whether a week before a survey has an ailment. When respondents answered yes, the next question was whether ailment is detrimental to work activities. The two health-related variables were also included in our analysis to see whether idle is also affected by ailment status. Variables and standard deviation of variables used is depicted in Table 1. Following the allocation of time model with a view to knowing the probability of individual in seeking the job $\left(\mathrm{Un}_{\mathrm{i}}\right)$ or staying as 'idle $\mathrm{e}_{\mathrm{i}}$, we use a simple probabilistic model as follows:

Potential youth can be drawn into the following model:

$$
\mathrm{Un}_{\mathrm{i}}=\mathrm{f}\left(\mathrm{Sex}_{\mathrm{i}}, \text { loc }_{\mathrm{i}}, \mathrm{Mar}_{\mathrm{i}}, \mathrm{Educ}_{\mathrm{i}}, \mathrm{HH}-\text { Income }_{\mathrm{i}}, \mathrm{Health}_{\mathrm{i}}\right)
$$

Passive youth is denoted here as "idle" youth in the following model,

$$
\text { "Idle } \mathrm{i} \text { = f (Sex, Loc, Mar, Educ, HH-Income, Health) }
$$

\section{Findings}

As has been mentioned earlier, the probability of youth in seeking the job, which is assumed as potentially active youth, is different from youth probability of becoming "idle". We estimate the model of each classified youth, which can be seen in Table 2. Column 2 of Table 2 represents the marginal effect of youth seeking the job or temporary seeking the jobs. Column 3 of Table 2 represents the marginal effect of each explanatory variable on the youth probability of becoming "idle". Column 4 of Table 2 involves a combination of data of individuals seeking the job either 'idle' as dependent variables or explanatory variables.

Male respondents are significantly different in their employability status compared to female counterparts, where males have much higher probability of seeking the job. In contrast, female respondents have much higher probability of becoming idle compared to male counterparts (marginal effect is -0.0282731 column 3 Table 2). Implicitly, young males are much more active in seeking the job compared to females (marginal effect is 0.0333656 in column 2 in Table 2). Our findings revealed that during the transition from schooling to labour market, there is a tendency of forcing males to enter the job. This may reflect that the breadwinner tends to be males than female. A relatively greater probability of females to become idle reflected various possible factors. It is likely that women at the period of transition have difficulties in determining schooling, working or marriage decision. Our study confirmed that in earlier 1980s, unidentified younger ages as 'else' might reflect women preparing for entering the next level of education. Some waited for marriage. During that time women tended to become idle (Elfindri, 1989).

Viewed in depth, gender bias in work activity is visible with female being preferred than males. Women in Indonesia are relatively passive in their work status compared to man. There would be greater probability that unmarried youth becomes idle. This may reflect the real situation in labour markets where limited formal job market postpones them to decide whether to enter job market or continue their further education.

Our data also reveals that marital status explains the probability of youth either seeking the jobs or becoming 'idle' and increased the probability of unmarried as either job seekers or becomes 'idle'. This reflects that marriage couples may force individual (particularly males) to enter the jobs because of household responsibility. The residential effect also conduces to significant increase in probability of seeking the job and idleness. Owing to the fact that a lot of work opportunity is available in urban areas, the competition to get a job may increase unemployment probability. To a certain extent, the difficulty to obtain a job makes youth choose to be idle (see Belfield \& Levin, 2012). 
Table 2. Marginal effect on probability of youth preferring the job seeking, inactive 'idle' and their combination

\begin{tabular}{|c|c|c|c|}
\hline Variables & $\begin{array}{l}\text { Potential Youth Seeking } \\
\text { for jobU }(\mathrm{dy} / \mathrm{dx}) \mathrm{a}\end{array}$ & $\begin{array}{l}\text { Inactive } \quad \text { Youth } \\
\text { "Idle" (dy/dx)a }\end{array}$ & $\begin{array}{l}\text { Youth Idleness" } \\
(1+2)(d y / d x) a\end{array}$ \\
\hline (1) & (2) & (3) & (4) \\
\hline \multicolumn{4}{|l|}{ Individual characteristics } \\
\hline - Sex $($ male=1) & $\begin{array}{l}0.0333656 \\
(0.00318)^{* *}\end{array}$ & $\begin{array}{l}-0.0282731 \\
(0.00361)^{* *}\end{array}$ & $\begin{array}{l}-0.0201488 \\
(0.0055)^{* *}\end{array}$ \\
\hline - Marital Status (Unmarried=1) & $\begin{array}{l}0.067788 \\
(0.00313)^{* *}\end{array}$ & $\begin{array}{l}0.0744313 \\
(0.00253)^{* *}\end{array}$ & $\begin{array}{l}-0.0098388 \\
(0.00617)\end{array}$ \\
\hline - Urban (Urban=1) & $\begin{array}{l}0.0255456 \\
(0.00313)^{* *}\end{array}$ & $\begin{array}{l}0.0026821 \\
(0.00275)\end{array}$ & $\begin{array}{l}0.0331262 \\
(0.00458)^{* *}\end{array}$ \\
\hline \multicolumn{4}{|c|}{$\begin{array}{l}\text { Education completed (Higher education as } \\
\text { references) }\end{array}$} \\
\hline - Ed-1 ( >=SD=1) & $\begin{array}{l}-0.0498384 \\
(0.00499)^{* *}\end{array}$ & $\begin{array}{l}0.0232429 \\
(0.00582)^{* *}\end{array}$ & $\begin{array}{l}-0.0296617 \\
(0.00897)^{* *}\end{array}$ \\
\hline - $\mathrm{Ed-2}(\mathrm{SMP}=1)$ & $\begin{array}{l}-0.0230501 \\
(0.00525)^{* *}\end{array}$ & $\begin{array}{l}0.0323534 \\
(0.00655)^{* *}\end{array}$ & $\begin{array}{l}-0.0646243 \\
(0.00958)^{* *}\end{array}$ \\
\hline - Ed-3 (SMA=1) & $\begin{array}{l}0.0261647 \\
(0.00615)^{* *}\end{array}$ & $\begin{array}{l}0.0269068 \\
(0.00625)^{* *}\end{array}$ & $\begin{array}{l}-0.0379173 \\
(0.00929)^{* *}\end{array}$ \\
\hline - Ed-4 (Religious school=1) & $\begin{array}{l}0.0042683 \\
(0.00641)\end{array}$ & $\begin{array}{l}0.004277 \\
(0.0056)\end{array}$ & $\begin{array}{l}-0.0413325 \\
(0.00998)^{* *}\end{array}$ \\
\hline - Ed-5 (Vocational=1) & $\begin{array}{l}0.0256724 \\
(0.00728)^{* *}\end{array}$ & $\begin{array}{l}-0.009337 \\
(0.00618)\end{array}$ & $\begin{array}{l}-0.0512631 \\
(0.01092)^{* *}\end{array}$ \\
\hline - Ed6 (Packet A=1) & $\begin{array}{l}0.0255199 \\
(0.03568)\end{array}$ & $\begin{array}{l}0.0372749 \\
(0.0393)\end{array}$ & $\begin{array}{l}0.0046325 \\
(0.05293)\end{array}$ \\
\hline - Ed7 (Packet B=1) & $\begin{array}{l}-0.0243576 \\
(0.01774)\end{array}$ & $\begin{array}{l}0.0334947 \\
(0.02394)\end{array}$ & $\begin{array}{l}-0.05143 \\
(0.03349)\end{array}$ \\
\hline \multicolumn{4}{|c|}{ HH Income (Q-5 richest as a references) } \\
\hline - Q-1(Expenditures $<20 \%=1)$ & $\begin{array}{l}0.0454497 \\
(0.0058)^{* *}\end{array}$ & $\begin{array}{l}0.0360092 \\
(0.00514)^{* *}\end{array}$ & $\begin{array}{l}0.0373936 \\
(0.00688)^{* *}\end{array}$ \\
\hline - Q-2 (Expenditures21-40\%=1) & $\begin{array}{l}0.0406599 \\
(0.00542)^{* *}\end{array}$ & $\begin{array}{l}0.0297192 \\
(0.00489)^{* *}\end{array}$ & $\begin{array}{l}0.0168396 \\
(0.00678)^{*}\end{array}$ \\
\hline - Q-3 (Expenditures41-60\%=1) & $\begin{array}{l}0.0390599 \\
(0.00531)\end{array}$ & $\begin{array}{l}0.0172161 \\
(0.00464)^{* *}\end{array}$ & $\begin{array}{l}0.02175 \\
(0.00671)^{* *}\end{array}$ \\
\hline - Q-4(Expenditures61-80\%=1) & $\begin{array}{l}0.0242376 \\
(0.00501)\end{array}$ & $\begin{array}{l}0.0123392 \\
(0.00454)^{* *}\end{array}$ & $\begin{array}{l}0.0011408 \\
(0.00672)\end{array}$ \\
\hline \multicolumn{4}{|l|}{ Health and Condition } \\
\hline - Ailment (yes=1) & $\begin{array}{l}0.0000467 \\
(0.00535)\end{array}$ & $\begin{array}{l}0.0039051 \\
(0.00487)\end{array}$ & $\begin{array}{l}0.004743 \\
(0.00813)\end{array}$ \\
\hline - Disturbing (Yes=1) & $\begin{array}{l}-0.0109516 \\
(0.00679)\end{array}$ & $\begin{array}{l}0.0096678 \\
(0.00669)\end{array}$ & $\begin{array}{l}-0.0085227 \\
(0.01097)\end{array}$ \\
\hline Wald chi-square test & 967.24 & 586.61 & \\
\hline Log pseudo likelihood & -17553.322 & -15081.234 & \\
\hline Pseudo R2 & 0.0296 & 0.0246 & \\
\hline Observation & 49186 & 49186 & \\
\hline
\end{tabular}
(a) $\mathrm{dy} / \mathrm{dx}$ is for discrete change of dummy variable from 0 to 1 ;
(b) Standard Error in parenthes;
(c) ** Significance at $1 \%$;
(d) * Significance at $5 \%$. 
Education of youth may broaden their shadow market wage (Becker, 1965). According to our data, the youth probability of getting unemployed gets increased when their education becomes higher. From lower level to lower middle of education, the probability of youth to seek the jobs is much lower compared to respondents graduating from upper middle levels. Among middle level of education, vocational graduates (also religious schools graduates) were unemployed much higher compared to lower level graduates, and this has also been confirmed in the previous study (Manning \& Sumarto, 2011).

Our study also reveals that informal education, through formal certificates, does not decrease the youth probability of becoming idle. Also religious schools graduates do not reduce the idleness, which can be shown in the marginal effect coefficients of ed-4 is 0.004277 (not statistically significant). Vocational graduates are the only ones who reduce the probability of becoming idle (the marginal effects of vocational education (ed-5) in column 3 and four decline concerning both probability of youth illness and combined sample (column 4 in Table 2). This means that vocational education may reduce the graduate probability of getting idle or unemployed. This evidence may be consistent with the rate of return studies, where there is an indication of declining economic returns to education in Indonesia (Losina, Miller, \& Salim, 2013), or even poor in graduate skills at all levels of education (Suryadarma, 2011).

Youth from lower household economic status (Q-1 and Q-2) seeking the jobs is significantly higher compared to middle or higher income groups. Among middle to upper income groups the probability of youth seeking the jobs declined. This finding may reflect that household support for young adults among higher economic status reduce their probability to become job seekers. This implies that youth living in poor households are inclined to have poor school quality and prolong their status during transition of getting idle. But for the rich households, the greater probability of youth idleness is due to household supports. A greater intra-household distribution of assets may let them stay at idle position, or even unproductive (see also Chetty et al., 2014). There is unclear effect of 'qualitative' response of health on the probability of youth becoming unemployed. In our data, both ailment and respondents recognized on the effect of ailment on job do not statistically influence the youth probability of becoming and seeking the jobs, or even staying idle.

\section{Conclusion}

In this paper we have employed data from the 2012 Susenas to investigate the issue of idleness and comparison with unemployment among youth population. Using logistic regression models, we have demonstrated that gender, residential status, marital status, education, households income and illness status have in general significant impacts on the youth probability of becoming idle. Our results show that women tend to become idler than men. In other words, men tend to become unemployed. Unmarried people tend to become idle and unemployed compared to those who are married. There is no clear evidence of residential status, but youth unemployment is significantly higher in urban than in rural areas.

Education level of respondents is not certain to increase likelihood of respondents to be idle until lower secondary schools and decline slightly. The vocational education is the only one that is able to reduce the youth probability of becoming idle, while informal education and religious schools tends to increase youth idleness. Idle youths are more likely to appear among the first and second income groups, groups of households among poor and near poor. However, idle youth is not only among poor but also among middle and higher income families. The analysis also highlights the difference of illness status, yet our study does not have a clear indication if poor health status increases the youth probability of becoming idle.

Policy makers face much challenge as they attempt to improve the status of youth as youth can contribute to economic improvements. In this paper we have discussed how poor skills were evident among school drop- outs or even finished attending education. Other aspects that are very important are not only the problems of unemployment among young age people but also the issue of idleness. Reducing idleness among youth means to prompt youth to become more productive in labour market. Reaching unreachable youth and providing them with any required skills calls for a serious attention. The effect of such initiatives may contribute to improving youth readiness to enter labour markets.

\section{References}

Adelman, R. (2011). Idleness, Contemplation and the Aesthetic, 1750-1830. Cambridge University Press. http://dx.doi.org/10.1017/CBO9780511675706

Aizer, A., Shari, E., Joseph, F., \& Adriana, L. (2014). The Long Term Impact of Cash Transfers to Poor Families. Working Paper 20103, NBER Working Paper Series.

Alatas, S. H. (1977). The Myth of the Lazy Native: A Study of the image of the Malays, Filipinos, and Javanese 
from 16th to 20th Century and its function in the ideology of colonial capitalism. Frank Class and Company Limited.

Almeida, R., Jere, B., \& David, R. (2012). The Right Skills for the Job? Rethinking Training Policies for Workers, Human Development perspectives, The World Bank. http://dx.doi.org/10.1596/978-0-8213 $-8714-6$

Banerji, A., Vivian, L., Jamie, M., Amy, R., Jose, M. S., Poonam, A., ..., Tanya, M. (2013). An 'E.Y.E.' To the Future: Enhancing Youth Employment. World Bank Human Development Sections, Chapter 4.

Becker, G. S. (1965). A Theory of the Allocation of Time. Economic Journal, 75(229), 493-517. http://dx.doi.org/ $10.2307 / 2228949$

Belfiels, C. R., \& Henry, M. L. (2012). The Economics of Investing in Opportunity Youth. The World Bank.

Bruce, J. B., Barbara, J. B., Anderson, D. S., \& John, A. K. (1981). The Structure of Idleness-In-School and Dropout Adolescent. Sociology of Education, 54(2).

Chetty, R., Nathaniel, H., Patrick, K., Emmanuel, S., \& Nicholas, T. (2014). Is the United Stated still a land of Opportunity Recent Trends in Intergenerational Mobility. American Economic Review, 104(5), 141-153. http://dx.doi.org/10.1257/aer.104.5.141

Elfindri, \& Jahen, F. R. (2014b). Rate of Returns to Formal and Non-Formal Education in Indonesia. Drafts.

Elfindri, \& Jalal, F. R. (2014a). Bonus Demografi Demi Kejayaan Bangsa. Drafts.

Elfindri. (1989). Female Labour Force Participation Rates in Indonesia. Unpublished MA Thesis, Flinders University, South Australia.

Ireys, H. T., Salkever, D. S., Kolodner, K. B., \& Bijur, P. E. (1996). Schooling, Employment, and Idleness in Young Adults with Serious Physical Health Conditions: Effects of Age, Disability Status, and Parental Education. J. Adolescent Health, 19(1), 25-33. http://dx.doi.org/10.1016/1054-139X(95)00095-A

Jalal, F., Muchlas, S., Mae, C. C., Andrew, B. R., \& Siwage, D. N. (2009). Teacher Certification in Indonesia: A Strategy for Teacher Quality Improvement. Ministry of Education and the World Bank.

Khimm, S. (2012). Why more Americans are wasting their youth than Europeans. The Washington post.

Kirkegaard, J. F. (2012). Youth Unemployment in Europe: More Complicated than It Looks. Economist.

Lee, J. N., \& David, N. (2013). Cognitive skills and youth labour market outcomes. Background paper for The World Development Report 2013.

Ljungqvist, L. (2000). Economic Underdevelopment: The Case of a missing market for human capital. In P. Bardhan, \& C. Udry (Eds.), Readings in Development Economics, Microeconomics (Vol. 1, pp. 123-144).

Losina, P., Paul, W. M., \& Ruhul, S. (2013). Declining rates of return to education: Evidence for Indonesia. Bulletin of Indonesian Economic Studies, 49(2), 213-236. http://dx.doi.org/10.1080/00074918.2013.809842

Manning, C., \& Sudarno, S. (2011). Employment, Living Standards and Poverty: Trends, Policies and Interactions. In C. Manning, \& S. Sumarto (Eds.), Employment, Living Standards and Poverty in Contemporary Indonesia. Institute of Southeast Asian Studies, Singapore.

Mason, A., \& Tomoko, K. (2008). East Asian economic development: Two demographic dividends. Journal of Asian Economics, 19, 389-399. http://dx.doi.org/10.1016/j.asieco.2008.09.006

Mazzocco, M., Claudia, R., \& Shintaro, Y. (2014). Labour supply and household dynamics. American Economic Review: Paper and Preceedings, 104(5), 354-359. http://dx.doi.org/10.1257/aer.104.5.354

Ministry of Religious Affair. (2007). Buku Statistik Pendidikan Agama dan Keagamaan: Tahun Ajaran 2006/2007. Book of Statistics and religious Education 2006/2007. Ministry of Religious Affairs, Jakarta.

Permani, R. (2011). Educational Challenges with Special Reference To Islamic Schooling. In C. Manning, \& S. Sumarto (Eds.), Employment, Living Standards and Poverty in Contemporary Indonesia. Institute of Southeast Asian Studies, Singapore.

Salant, S. W. S. (1977). Search Theory and duration data: A Theory of Sorts. The Quarterly Journal of economics, XCI(1), 39-58. http://dx.doi.org/10.2307/1883137

Suryadarma, D. (2011). The Quality of Education: International Standing and Attempts at Improvement. In C. Manning, \& S. Sumarto (Eds.), Employment, Living Standards and Poverty in Contemporary Indonesia. Institute of Southeast Asian Studies, Singapore.

The Economists Magazine. (2013). Generation jobless.

Thomas, D. (2000). Intra-household Resource Allocation: An Inferential Approach. In P. Bardhan, \& C. Udry (Eds.), Readings in Development Economics, Empirical Microeconomics (Vol. 2, pp. 69-98). 


\section{Notes}

Note 1. "This research is not sponsored by any agency and fully independent research by the authors. The opinions and conclusions expressed belong to the authors and do not represent any of the opinion and policy of government of Indonesia, or any agency of special government."

Note 2. "See Evi Nurfiana and Aris Ananta (2014) "The Role of Population Dynamics in Reaching "The Future We Want: The Case of Indonesia", draft."

Note 3. "According to CBS of Indonesia, persons included here as "idle' are those who are neither in work nor education, things look even worse."

Note 4. "The Economist (2013) calculates that, all told, almost 290 million are neither working nor studying: almost a quarter of the planet's youth. In addition, many of the "employed" young people have only informal and intermittent jobs. In rich countries more than a third, on the average, are contemporary contracts, which make it hard to gain skills. In poorer ones, according to the World Bank, a fifth are unpaid family laborers or working in the informal economy. All in all, nearly half of the world's young people are either outside the formal economy or contributing less productively than they could."

Note 5. "In the past those who were not at school could count on spending equivalent amounts of time in employment. However, employment opportunities have declined for adolescents during the past three decades; so one problem facing those who are no longer at school is simply to fill the vacuum of idleness."

Note 6. "Quality of education can be measured through mathematics, science and reading improvements. The data shows the Indonesian children have not improved significantly in 2001, 2004 and 2009 respectively. Children coming from poor households until households' reaches $60 \%$ of expenditures class are among the poor achievement (see Fernandez, 2014)."

Note 7. "At the younger age cohorts, an active youth can be seen from their main activities. If they are seeking job, or temporary unemployed due to various reasons, they seem to depend on skills as well as demand. However, a passive youth, assumed a potential youth, is one without clear daily activities. A passive youth may be has a serious impact on their future life."

Note 8. "It is recognized that when an individual has disability or illness, he or she may be temporarily or permanently unable to do the main activities during the census conducted. However, the number of youth disability may be not more that $2 \%$. So it is possible to put them as an economically active population."

Note 9. "A study of youth idleness in US in 2012 reported by Belfield and Levin (2012) indicated that youth idleness characteristics are those who have all opportunities of $17.3 \%, 26 \%$ due to poverty, $24.3 \%$ to crime, $5.8 \%$ to disability and $2.9 \%$ to substantive abuse. Biddle et al (1981) also reported a time use study for the idleness youth, showing that the activities reported by those no longer at school differed between the two countries. Australian school leavers were found more likely to engage in sports and recreation, whereas American dropouts were more likely to report visiting, loafing, and problem behaviors. Related findings suggest that these differences reflect opportunities available in the two societies rather than adolescents' preferences."

Note 10. "After introducing Presidential Instruction (known as Inpres Program) of fulfilling basic education since 1974, the new "SD Inpres" throughout regions have been able to upgrade the enrolment rates of school age population (Duflo, 2001). Since 2004, Indonesia declared its target of $20 \%$ of government budget for to education sector. Besides decentralization of education, operational assistance for school (Bantuan Operasional Sekolah, BOS) is given along with a new form of policy. The aim of the program is to enlarge opportunity of children to obtain learning process through non-formal education. The policy is under directorate of non-formal education called learning groups ("Kejar Paket, Kelompok Belajar): Kejar Paket A for primary level certificate, Kejar Paket $B$ for lower secondary and Kejar Paket $C$ for upper secondary education. In the Kejar Paket, a non-formal education process is carried out by NGOs or technical services units of education, "Unit Pelayanan Teknis Pendidikan" reaching young population. They were also community education teaching basic mathematics and reading for primary level education, and mostly life skills for upper secondary education."

\section{Copyrights}

Copyright for this article is retained by the author(s), with first publication rights granted to the journal.

This is an open-access article distributed under the terms and conditions of the Creative Commons Attribution license (http://creativecommons.org/licenses/by/3.0/). 